\title{
EDITORIAL
}

\section{Unraveling the enigma that is neonatal necrotizing enterocolitis}

Journal of Perinatology (2014) 34, 729-730; doi:10.1038/jp.2014.155

'When all the details fit in perfectly, something is probably wrong with the story'

-Charles Baxter, Burning Down the House: Essays on Fiction

Neonatal necrotizing enterocolitis (NEC) affects over 4000 premature infants every year in the United States, and one-third of the infants who develop NEC will die from the disease. ${ }^{1}$ The financial impact of NEC is significant, with an estimated annual cost of up to $\$ 1$ billion in the United States alone. ${ }^{2,3}$ While NEC has been recognized as a disease of premature infants for over 4 decades, ${ }^{4}$ understanding of its pathophysiology is still incomplete. A major reason behind this gap in understanding is that what we as clinicians diagnose as NEC is not clearly defined, and it is very likely a common final pathway as opposed to a singular disease process. $^{5}$

NEC was first described in the 1950s and 60s. ${ }^{4,6,7}$ Initially, NEC was considered to be a syndrome of vomiting, abdominal distention, gastrointestinal bleeding and shock due to ulcerations in the gastrointestinal tract, particularly the terminal ileum. ${ }^{4}$ At the time, the disease occurred mainly in infants born less than $1500 \mathrm{~g}$ and who were doing well and tolerating feedings, and most infants with NEC died. ${ }^{4}$ By the late 1970s, researchers had classified NEC through Bell's staging, grouping infants by severity ${ }_{i}^{8}$ however, NEC continued to be considered a singular disease. In the 1980s, neonatology experienced major advances that allowed survival of more premature infants. Because of this, the infants who developed NEC changed as well. In the 1970s, the average infant who developed NEC had a birth weight of $1645 \mathrm{~g}$ and a $45 \%$ chance of survival. In the 1980s, however, the average birth weight dropped to $1505 \mathrm{~g}$, while the survival increased to $82 \% .^{9}$ Around this time, it became clear that the 'NEC' developed by this new cohort of extremely low birth weight infants was actually comprised of two separate disease processes. ${ }^{10}$ The first group is what we traditionally considered to be NEC. These infants are predominantly extremely premature infants, ${ }^{1}$ who most often develop injury when they reach a corrected gestation age between 28 and 32 weeks. ${ }^{11,12}$ NEC is thought to occur in these infants when intestinal bacteria penetrate the immature intestinal epithelial barrier defenses, leading to bacterial invasion of subepithelial tissues, resulting in development of inflammation and tissue necrosis. ${ }^{13,14}$ In contrast, the second group of infants develops spontaneous intestinal perforation (SIP), which is distinctly different from NEC. ${ }^{15,16}$ While NEC is essentially an inflammatory disease, SIP is thought to have a different pathophysiology. SIP has less of an inflammation component, ${ }^{17}$ develops at a different time in life and has a different, non-ischemic histopathology than NEC. ${ }^{18}$ In our lab, we have documented significant differences in the effects that NEC and SIP have on goblet and Paneth cells of the small intestinal epithelium. $^{19}$

Because these two diseases can occur in similar patient cohorts, and especially as they both affect the small intestine, it is vital to distinguish between these two pathologies when developing clinical studies. The study by Gordon et al. ${ }^{18}$ does an outstanding job of defining a normative timeline for medical NEC compared to surgical NEC and SIP with a very large national data set. By taking measures to derive the cleanest data set possible, the authors have provided clinicians an important blueprint of when these diseases strike, which will allow neonatologists and surgeons to better distinguish between NEC and SIP. This is vital, as evidence is clearly showing differences in outcomes between infants with surgical NEC and SIP. ${ }^{20}$

NEC remains one of the greatest challenges that affect premature infants and plague the physicians and nurses who take care of them. As researchers are attempting new strategies to prevent NEC, it is critical that we do not confound our studies with infants who have intestinal pathology that is not in fact NEC. By generating clean, normative data from large databases, studies like the one by Gordon et al. will greatly enhance these efforts.

\section{CONFLICT OF INTEREST}

The author declares no conflict of interest.

\section{ACKNOWLEDGEMENTS}

This work was supported by the NIH/NIDDK (DK083677, DK097335), and by the Children's Miracle Network.

\author{
SJ McElroy \\ Department of Pediatrics, University of lowa, \\ lowa City, IA, USA \\ E-mail: steven-mcelroy@uiowa.edu
}

\section{REFERENCES}

1 Fitzgibbons SC, Ching Y, Yu D, Carpenter J, Kenny M, Weldon C et al. Mortality of necrotizing enterocolitis expressed by birth weight categories. J Pediatr Surg 2009; 44(6): 1072-1075.

2 Udagawa N, Takahashi N, Katagiri T, Tamura T, Wada S, Findlay DM et al. Interleukin (IL)- 6 induction of osteoclast differentiation depends on IL-6 receptors expressed on osteoblastic cells but not on osteoclast progenitors. J Exp Med 1995; 182(5): 1461-1468.

3 (U.S.), N.C.f.H.S. National Vital Statistics Reports 2011; 60(1): 1-104.

4 Mizrahi A, Barlow O, Berdon W, Blanc WA, Silverman WA. Necrotizing Enterocolitis in Premature Infants. J Pediatr 1965; 66: 697-705.

5 Gordon P, Christensen R, Weitkamp JH, Maheshwari A. Mapping the new world of necrotizing enterocolitis (NEC): review and opinion. EJ Neonatol Res 2012; 2(4): $145-172$.

6 Rabl R. Necrotizing enterocolitis in premature infants. Beitr Pathol Anat 1957; 117(2): 266-282

7 Berdon WE, Grossman H, Baker DH, Mizrahi A, Barlow O, Blanc WA. Necrotizing enterocolitis in the premature infant. Radiology 1964; 83, 879-887.

8 Bell M.J, Ternberg JL, Feigin RD, Keating JP, Marshall R, Barton L et al. Neonatal necrotizing enterocolitis. Therapeutic decisions based upon clinical staging. Ann Surg 1978; 187(1): 1-7.

9 Grosfeld JL, Cheu H, Schlatter M, West KW, Rescorla FJ. Changing trends in necrotizing enterocolitis. Experience with 302 cases in two decades. Ann Surg 1991; 214(3): 300-306.

10 Aschner JL, Deluga KS, Metlay LA, Emmens RW, Hendricks-Munoz KD. Spontaneous focal gastrointestinal perforation in very low birth weight infants. J Pediatr 1988; 113(2): 364-367.

11 Covert RF, Neu J, Elliott MJ, Rea JL, Gimotty PA. Factors associated with age of onset of necrotizing enterocolitis. Am J Perinatol 1989; 6(4): 455-460. 
12 Yee WH, Soraisham AS, Shah VS, Aziz K, Yoon W, Lee SK. Canadian Neonatal Network. Incidence and timing of presentation of necrotizing enterocolitis in preterm infants. Pediatrics 2012; 129(2): e298-e304.

13 Chen AC, Chung MY, Chang JH, Lin HC. Pathogenesis implication for necrotizing enterocolitis prevention in preterm very-low-birth-weight infants. J Pediatr Gas troenterol Nutr 2014; 58(1): 7-11.

14 Neu J, Walker WA. Necrotizing enterocolitis. N Engl J Med 2011; 364(3): 255-264.

15 Vermont Oxford Network Steroid Study Group. Early postnatal dexamethasone therapy for the prevention of chronic lung disease. Pediatrics 2001; 108(3): 741-748.

16 Gordon PV, Young ML, Marshall DD. Focal small bowel perforation: an adverse effect of early postnatal dexamethasone therapy in extremely low birth weight infants. J Perinatol 2001; 21(3): 156-160.
17 Chan KY, Leung FW, Lam HS, Tam YH, To KF, Cheung HM et al. Immunoregulatory protein profiles of necrotizing enterocolitis versus spontaneous intestinal perforation in preterm infants. PLoS One 2012; 7(5): e36977.

18 Gordon PV, Attridge JT. Understanding clinical literature relevant to spontaneous intestinal perforations. Am J Perinatol 2009; 26(4): 309-316.

19 McElroy SJ, Prince LS, Weitkamp JH, Reese J, Slaughter JC, Polk DB. Tumor necrosis factor receptor 1-dependent depletion of mucus in immature small intestine: a potential role in neonatal necrotizing enterocolitis. Am J Physiol Gastrointest Liver Physiol 2011; 301(4): G656-G666.

20 Wadhawan R, Oh W, Hintz SR, Blakely ML, Das A, Bell EF et al. Neurodevelopmental outcomes of extremely low birth weight infants with spontaneous intestinal perforation or surgical necrotizing enterocolitis. J Perinatol 2014; 34(1): 64-70. 